\title{
Agaro-Oligosaccharides Prevent Myostatin Hyperexpression and Myosin Heavy Chain Protein Degradation in C2C12 Myotubes Induced by Tumor Necrosis Factor- $\alpha$
}

\author{
Ikuya Shirai, Takehiko Sakai, Katsuhiro Shiba, Yuji Uzuhashi, Koji Karasawa* \\ Research \& Development, Ina Food Industry Co., Ltd., Ina, Japan \\ Email: ^k-kouji@kantenpp.co.jp
}

How to cite this paper: Shirai, I., Sakai, T., Shiba, K., Uzuhashi, Y. and Karasawa, K. (2018) Agaro-Oligosaccharides Prevent Myostatin Hyperexpression and Myosin Heavy Chain Protein Degradation in C2C12 Myotubes Induced by Tumor Necrosis Factor- $\alpha$. CellBio, 6, 23-34.

https://doi.org/10.4236/cellbio.2018.72003

Received: May 15, 2018

Accepted: June 11, 2018

Published: June 14, 2018

Copyright $\odot 2018$ by authors and Scientific Research Publishing Inc. This work is licensed under the Creative Commons Attribution International License (CC BY 4.0).

http://creativecommons.org/licenses/by/4.0/

(c) () Open Access

\begin{abstract}
Myostatin is a major factor involved in the regulation of skeletal muscle protein mass. High myostatin levels have been associated with an increase in myotube shrinkage. Enhanced myostatin expression is caused by pro-catabolic reactions involving compounds such as tumor necrosis factor (TNF)- $\alpha$. The present study investigated the effects of agaro-oligosaccharides (AOSs) on hypercatabolism of myotubes exposed to TNF- $\alpha$. C2C12 myotubes exposed to TNF- $\alpha$ in the presence or absence of AOSs. Myotube exposure to TNF- $\alpha$ resulted in a reduction in the amount of myosin heavy chain $(\mathrm{MyHC})$ protein and a decrease in myotube diameter, which was associated with increased myostatin mRNA expression. AOSs prevented TNF- $\alpha$-induced MyHC protein loss and restored normal myostatin mRNA levels, with agarobiose and agarotetraose effectively suppressing the hyperexpression of the mRNA. In addition, expression levels of the known myostatin inhibitors, latent transforming growth factor beta binding protein 3 (Ltbp3) and growth and differentiation factor-associated serum protein 1 (Gasp1) mRNAs, decreased more in TNF- $\alpha$-induced myotubes than in the TNF- $\alpha$-free control, possibly resulting in myostatin upregulation. However, AOSs restored nearly normal expression levels of Ltbp3 and Gasp1 mRNA, potentially suppressing myostatin expression. These findings suggest that AOSs could prevent myotube shrinkage induced by TNF- $\alpha$.
\end{abstract}

\section{Keywords}

Agaro-Oligosaccharides, Myotubes, Myosin Heavy Chain, Myostatin 


\section{Introduction}

Skeletal muscle is the most abundant tissue in the human body and is critical for locomotion and metabolic adaptation. It comprises approximately $40 \%-50 \%$ of the human body by weight and is mainly maintained by a balance between protein synthesis and degradation. Exercise, nutrients, and exogenous stimuli increase the rate of protein synthesis and increase muscle mass (hypertrophy), whereas starvation, immobilization, aging, and diseases increase the rate of protein degradation and markedly reduce muscle mass (atrophy) [1]. Muscle atrophy is defined as a decrease in the size of tissue or organ due to myotube shrinkage caused by the loss of organelles, cytoplasm, and proteins [2].

Many recent findings have highlighted a complex scenario whereby an intricate network of signalling pathways regulates the size of myotubes. Four major pathways (IGF1-Akt-FoxO, myostatin, $\mathrm{NF \kappa B}$ and glucocorticoids) relate and modulate one another at different levels, coordinating protein synthesis and degradation simultaneously during muscle atrophy [2]. Myostatin, a member of the transforming growth factor- $\beta$ (TGF- $\beta$ ) superfamily, is a potent negative regulator of skeletal muscle growth. Myostatin overexpression may cause muscle atrophy, whereas its inactivation can induce skeletal muscle hypertrophy [3]. Myostatin inhibits fast myosin heavy chain (MyHC) expression during myogenic differentiation in mouse [4]. Inversely, loss-of-function mutations of the myostatin gene lead to a hypertrophic phenotype in mammals [5] [6], and similar mutation in the human myostatin gene induces increased muscle mass [7].

Agar extracted from red seaweed has been used as a food substance in Japan for nearly 400 years. Agarose, the main component of the polysaccharide in agar, is a linear sugar chain consisting of alternating galactose (3-O-linked $\beta$-D-galactopyranose) and anhydrogalactose (4-O-linked 3,6-anhydro- $\alpha$-L-galactopyranose) residues. The $\alpha-1,3$ linkage of agarose is easily hydrolysed under acidic conditions, yielding agaro-oligosaccharides (AOSs) consisting of repeating agarobiose (Abi) units with galactose at the non-reducing end and anhydrogalactose at the reducing end (Abi, agarotetraose (Ate), agarohexaose (Ahe) and agarooctaose (Aoc); Figure 1). Recent studies have demonstrated the versatile biological activities of AOSs. Enoki et al. reported that AOSs can suppress the production of pro-inflammatory cytokines and the expression of inducible nitric oxide (NO) synthase (iNOS), an enzyme associated with the production of NO [8]. Higashimura et al. demonstrated that AOSs suppress high fat diet-induced dysbiosis, change microbial community function, and prevent colonic tumorigenesis in a mouse model [9]. Therefore, AOSs have potential as highly safe functional ingredients in food, drink, and/or pharmaceuticals.

AOSs exhibit high antioxidant activity [10], and several antioxidants, such as epigallocatechin-3-gallate [11], resveratrol [12], and flavones [13] are known to attenuate shrinkage in $\mathrm{C} 2 \mathrm{C} 12$ myotubes. In the present study, we investigated the inhibitory effects of AOSs on protein degradation and gene expressions related to myotube shrinkage induced by tumor necrosis factor (TNF)- $\alpha$. 


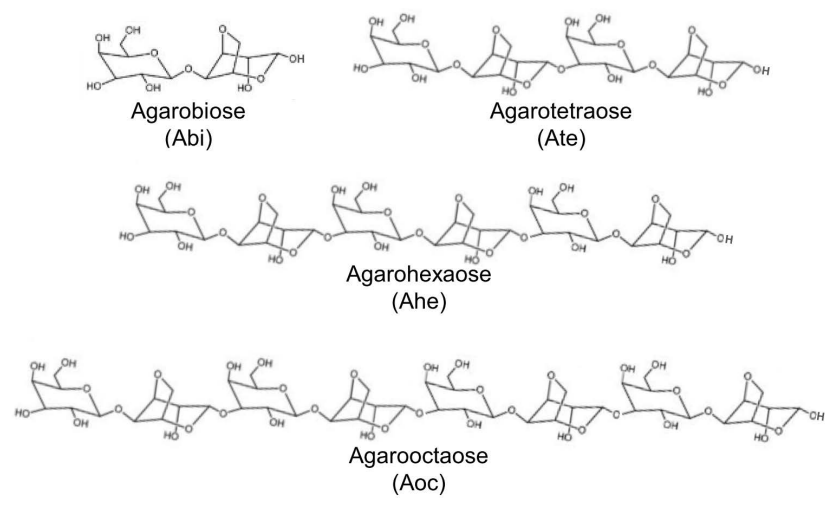

Figure 1. Chemical structures of AOSs.

\section{Materials and Methods}

\subsection{Materials}

Dulbecco's modified Eagle's medium (DMEM, High Glucose, with L-Glutamine, Phenol Red and HEPES), penicillin-streptomycin solution $(\times 100)$, Isogen, and GeneAce SYBR ${ }^{\circledR}$ qPCR Mix $\alpha$ were purchased from Wako Pure Chemical Industries (Osaka, Japan). TNF- $\alpha$ and antibody against hypoxanthine phosphoribosyltransferase 1 (Hprt1) were from Sigma-Aldrich Co. LLC (St. Louis, MO, USA). Fetal bovine serum (FBS) and horse serum (HS) were from Thermo Fisher Scientific Inc. (Waltham, MA, USA). Monoclonal anti-MyHC antibody as a primary antibody, donkey anti-sheep, goat anti-rabbit and goat anti-mouse peroxidase-conjugated IgG as secondary antibodies were from R\&D Systems, Inc (Minneapolis, MN, USA). All chemicals used in this study were of the highest analytical grade commercially available.

\subsection{Preparation of AOSs Mixture and Isolation of Each AOS}

AOSs mixture was prepared, and each AOS (i.e., Abi, Ate, Ahe and Aoc) was isolated as described by Enoki et al. [8]. The composition of Abi, Ate, Ahe and Aoc present in the AOSs mixture was $41.8 \%, 41.0 \%, 14.5 \%$ and $2.7 \%$, respectively, as measured by high performance liquid chromatography [14].

\subsection{Cell Cultures}

C2C12 skeletal myoblasts, a murine skeletal muscle cell line (DS Pharma Biomedical Co., Ltd., Osaka, Japan), were grown in DMEM supplemented with 10\% FBS, and maintained at $37^{\circ} \mathrm{C}$ in a humidified atmosphere of $5 \% \mathrm{CO}_{2}$ in air. For the experiments, cells were seeded at $35,000 \mathrm{cells} / \mathrm{cm}^{2}$ to obtain full confluence 2 $\mathrm{d}$ later. Differentiation to myotubes was induced by shifting confluent cultures to DMEM supplemented with $2 \%$ HS. The medium was changed every second day, and within $3 \mathrm{~d}$ most of the cells had fused to form myotubes. On day 4 , the cultures were treated with TNF- $\alpha(100 \mathrm{ng} / \mathrm{ml})$, AOSs mixture, or both in combination, and cells were collected after $24 \mathrm{~h}$ for mRNA assay or after $48 \mathrm{~h}$ for protein assay. 


\subsection{Cell Proliferation Assay}

Cells in 96-well plates were plated at 50\% confluence and synchronized in serum-free medium at $37^{\circ} \mathrm{C}$ for $24 \mathrm{~h}$. Then, cells were incubated in medium containing 10\% FBS, treated with AOSs mixture and incubated for a further $24 \mathrm{~h}$. A CellTiter $96^{\circledR}$ Aqueous One Solution kit (Promega, Madison, WI, USA) was used to measure cell viabilities. The optical density at $490 \mathrm{~nm}$ was determined using a microplate reader (Beckman Coulter, Inc., Brea, CA, USA).

\subsection{Preparation of Total RNA and Real-Time Reverse Transcription (RT)-Polymerase Chain Reaction (PCR)}

The total RNA from cells was extracted as described previously [15]. Real-time RT-PCR was conducted using a Mx3000P Real-Time PCR System (Agilent Technologies, Santa Clara, CA, USA) and GeneAce SYBR ${ }^{\circledR}$ qPCR Mix $\alpha$. The primers for amplifying myogenin, myosin light chain $3 f$ (Mlc3f), myostatin, latent transforming growth factor beta binding protein 3 (Ltbp3), growth and differentiation factor-associated serum protein 1 (Gasp1), and Hprt1 were designed using Probe Finder (Roche Diagnostics GmbH, Penzberg, Germany) and the probes were purchased from Hokkaido System Science (Hokkaido, Japan). Sequences of the specific primers are shown in Table 1 . The real-time RT-PCR reaction involved 40 cycles at $95^{\circ} \mathrm{C}$ for $5 \mathrm{~s}$ and $60^{\circ} \mathrm{C}$ for $30 \mathrm{~s}$. The relative amount of each mRNA was normalized using Hprt1 expression as an internal control. An expression index was calculated from the normalized relative amount in the absence of TNF- $\alpha$ to the normalized relative amount in the presence of TNF- $\alpha$. These analyses were carried out in at least triplicate, and representative results are presented.

\subsection{Myotube Diameter Measurements}

Images of myotubes exposed to TNF- $\alpha$ for $48 \mathrm{~h}$ were visualized at $\times 40$ magnification using an inverted light microscope and images were captured with a camera (Olympus, Tokyo, Japan). Using a slight modification of the method described by Williamson et al. [16], diameters of myotubes were measured from randomly selected six microscope fields from three different wells $(35 \mathrm{~mm})$ of control and treated conditions, and 50 myotubes per well (total 150 myotubes)

Table 1. Sequences of specific primers.

\begin{tabular}{ccc}
\hline \multirow{2}{*}{ Gene } & \multicolumn{2}{c}{ Forward } \\
\cline { 2 - 3 } & CCTTGCTCAGCTCCCTCA & Reverse \\
\hline myogenin & TGGAGTTGCATTCACTGG \\
Mlc3f & CAATGGCTGCATCAACTATGA & GCCATAGGTGTTCTTGAACTGG \\
myostatin & TGGCCATGATCTTGCTGTAA & CCTTGACTTCTAAAAAGGGATTCA \\
Ltbp3 & CATCTGCACGAACACACCA & TGACAGATGATAGCCGGAGA \\
Gasp1 & ACGACATGAACCCCAACCT & TTTCACACTCTCGCTTGCAG \\
Hprt1 & GCGTCGTGATTAGCGATGATG & CCTTCATGACATCTCGAGCAAG
\end{tabular}


were measured using ImageJ software (NIH, Frederick, MD, USA).

\subsection{Western Blot Analysis}

Myotubes were washed three times with ice-cold phosphate-buffered saline buffer (PBS), solubilized in lysis buffer $(150 \mathrm{mM} \mathrm{NaCl}, 0.1 \%$ Triton X-100, $0.5 \%$ sodium deoxycholate, $0.1 \%$ sodium dodecyl sulphate (SDS), $50 \mathrm{mM}$ Tris- $\mathrm{HCl}(\mathrm{pH}$ 8.0) and protease inhibitors (Sigma-Aldrich)), centrifuged at $15,000 \times \mathrm{g}$ for 10 $\min$ at $4^{\circ} \mathrm{C}$ and the supernatant was collected. Protein concentration was assayed according to Sedmak and Grossberg [17] using bovine serum albumin as the working standard. Equal amounts of protein $(10 \mu \mathrm{g})$ were heat-denatured in sample-loading buffer (62.5 mM Tris- $\mathrm{HCl}(\mathrm{pH} 6.8), 5 \%$ 2-mercaptoethanol, $2 \%$ SDS, $0.002 \%$ bromophenol blue, $10 \%$ glycerol), resolved on a SDS-polyacrylamide gel electrophoresis (PAGE), and transferred for $2 \mathrm{~h}$ to nitrocellulose membranes (Bio-Rad, Hercules, CA). The membranes were then blocked with Tris-buffered saline (TBS) containing $0.05 \%$ Tween (TBS-T) and 5\% non-fat dry milk. The membranes were incubated overnight with a monoclonal anti-MyHC antibody $(1: 20,000)$ or a polyclonal anti-Hprt1 antibody $(1: 2500)$ in TBS-T at $4^{\circ} \mathrm{C}$, then incubated with HRP-conjugated secondary antibody (1:20,000 for MyHC and 1:2000 for Hprt1) in TBS- $\mathrm{T}$ at $25^{\circ} \mathrm{C}$ for $1 \mathrm{~h}$. The membrane-bound immune complexes were detected by chemiluminescence using an Immuno Star LD (Wako Pure Chemical Industries) on photon-sensitive film (BioMax Light-1 film; Carestream Health, Inc., Rochester, NY, USA). Bands were quantified by densitometric analysis with ImageJ software.

\subsection{Statistical Analysis}

Data are expressed as the mean \pm standard error of mean (SEM). Differences were assessed using Student's t-test. Dunnett's multiple comparison test as post-hoc test after one-way analysis of variance. Details of each statistical analysis used are provided in the figure legends. Differences were considered significant when $P$-values were less than 0.05 .

\section{Results}

\subsection{Effects of AOSs on Cell Number and Differentiation}

Figure 2(A) shows the effects of AOSs on cell number and viability quantified by visually counting cells and by a cell proliferation assay, respectively. Neither the cell number nor the titer of cells treated with AOSs mixture (at 0.625, 2.5 and $10 \mu \mathrm{g} / \mathrm{ml}$ ) was significantly different from the control. Figure 2(B) shows the expression levels of myogenic markers [18], i.e., myogenin and Mlc3f mRNA. The expression levels of both mRNAs were not significantly different compared to the control.

\subsection{Effect of AOSs on Diameters of TNF- $\alpha$-Exposed Myotubes}

Figure 3(A) shows the effects of AOSs on the diameters of myotubes exposed to 

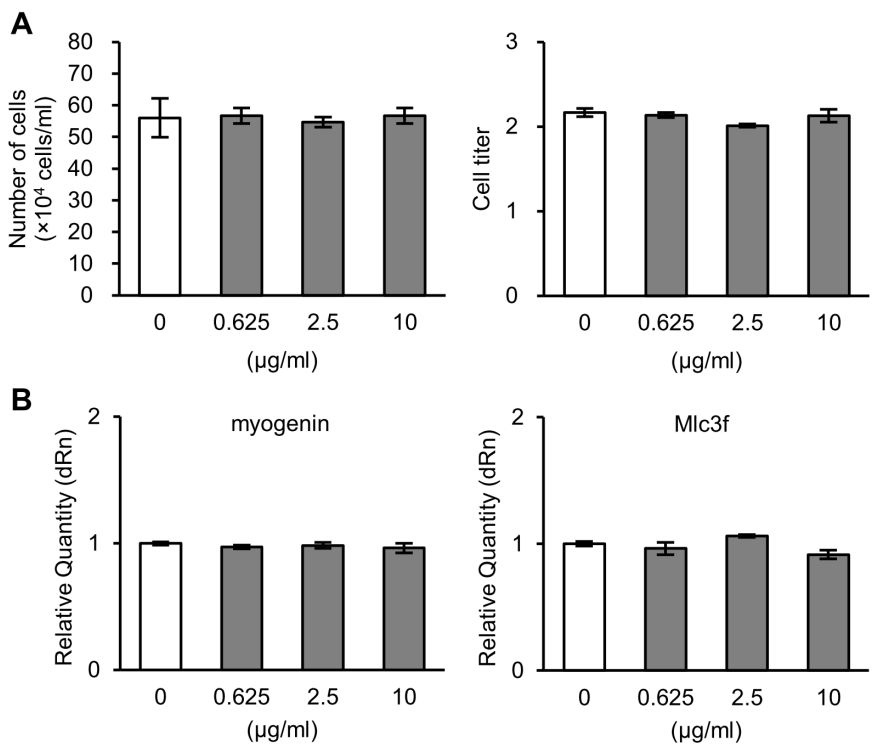

Figure 2. Cell numbers and differentiations in the absence or presence of AOSs mixture. (A) Cell number (left) and viability (right) following culture with AOSs mixture for $24 \mathrm{~h}$, were quantified by visual cell counting and the MTT assay, respectively. Data are expressed as the mean \pm SEM $(n=4)$; (B) Relative myogenin and Mlc3f mRNA expression. Data are expressed as the mean $\pm \operatorname{SEM}(n=3)$.
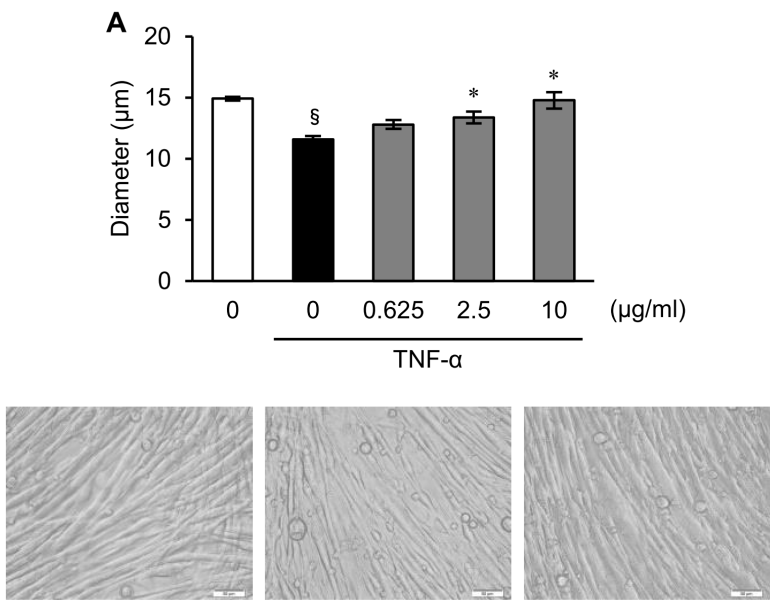

Figure 3. Diameters of myotubes in the absence or presence of AOSs mixture, exposed or not exposed to TNF- $\alpha$ for $48 \mathrm{~h}$. (A) Diameters of myotubes in the absence or presence of AOSs mixture, exposed or not exposed to TNF- $\alpha$. Fifty myotubes (/culture) from 3 wells/condition. ${ }^{\Im} P<0.05$ (Student's t-test, two-sided) compared to the TNF- $\alpha$-free control; ${ }^{\star} P<0.05$ (Dunnett's multiple comparison test, two-sided) compared to the TNF- $\alpha$-added control; (B) Images of myotubes at $\times 40$ magnification. TNF- $\alpha$-free control (left), TNF- $\alpha$-added control (center) and AOSs mixture-treated (at $10 \mu \mathrm{g} / \mathrm{ml}$, right). Scale bars indicate $50 \mu \mathrm{m}$.

TNF- $\alpha$. The diameters of myotubes exposed to TNF- $\alpha$ (TNF- $\alpha$-added control) were significantly decreased compared to the TNF- $\alpha$-free control. However, the diameters of myotubes exposed to TNF- $\alpha$ and treated with AOSs mixture (at 2.5 and $10 \mu \mathrm{g} / \mathrm{ml})$ were significantly $(P=0.0328$ at $2.5 \mu \mathrm{g} / \mathrm{ml}$ and $P=0.0113$ at 10 
$\mu \mathrm{g} / \mathrm{ml}$ ) increased compared to that of the TNF- $\alpha$-added control. Figure 3(B) shows microscopic images of the myotubes subjected to each treatment (TNF- $\alpha$-free control, left; TNF- $\alpha$-added control, center; AOSs mixture-treated (at $10 \mu \mathrm{g} / \mathrm{ml}$ ), right).

\subsection{Effect of AOSs on MyHC Protein Levels in TNF- $\alpha$-Exposed Myotubes}

Figure 4 shows the effects of AOSs on the amount of MyHC protein in myotubes exposed to TNF- $\alpha$. The amount of MyHC protein in myotubes exposed to TNF- $\alpha$ (TNF- $\alpha$-added control) was significantly decreased compared to the TNF- $\alpha$-free control. However, the amount of MyHC protein in myotubes exposed to TNF- $\alpha$ and treated with AOSs mixture (at $0.625,2.5$ and $10 \mu \mathrm{g} / \mathrm{ml}$ ) increased significantly in a dose-dependent manner compared to that of the TNF- $\alpha$-added control.

\subsection{Effect of AOSs on mRNA Expression in TNF- $\alpha$-Exposed Myotubes}

Figure 5 shows the effects of AOSs on myostatin, Ltbp3 and Gasp1 mRNA expression levels following the exposure of myotubes to TNF- $\alpha$. The level of myostatin mRNA expression in myotubes exposed to TNF- $\alpha$ (TNF- $\alpha$-added control) was significantly greater than that of the TNF- $\alpha$-free control. However, the level of myostatin mRNA expression in myotubes exposed to TNF- $\alpha$ and treated with AOSs mixture (at $0.625,2.5$ and $10 \mu \mathrm{g} / \mathrm{ml}$ ) was significantly lower than that of the TNF- $\alpha$-added control and decreased in a dose-dependent manner. In contrast, the level of Ltbp3 and Gasp1 mRNA expression in the

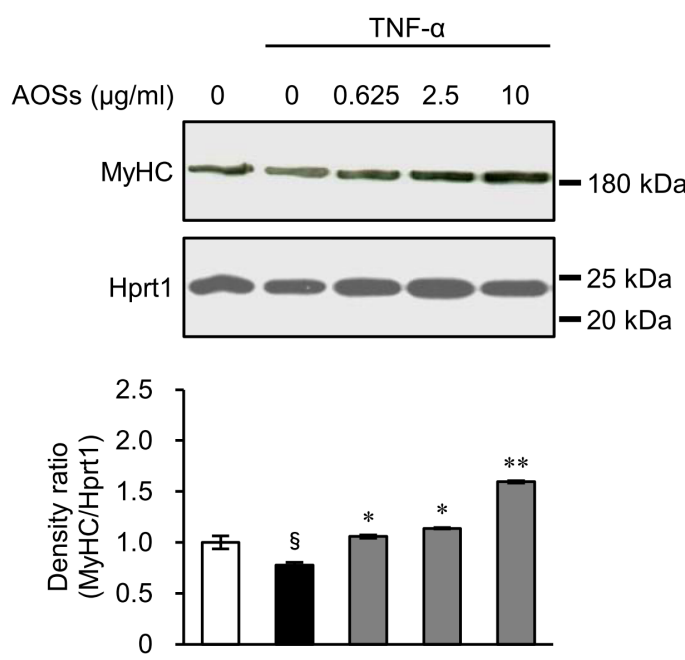

Figure 4. MyHC protein levels in myotubes in the absence or presence of AOSs mixture, exposed or not exposed to TNF- $\alpha$ for $48 \mathrm{~h}$. This analysis was carried out at least in triplicate, and a representative western blot is shown (top). Data (density ratio) are expressed as the mean $\pm \operatorname{SEM}(n=3)$ (bottom). ${ }^{\Im} P<0.05$ (Student's t-test, two-sided) compared to the TNF- $\alpha$-free control; ${ }^{\star} P<0.05,{ }^{*} P<0.01$ (Dunnett's multiple comparison test, two-sided) compared to the TNF- $\alpha$-added control. 


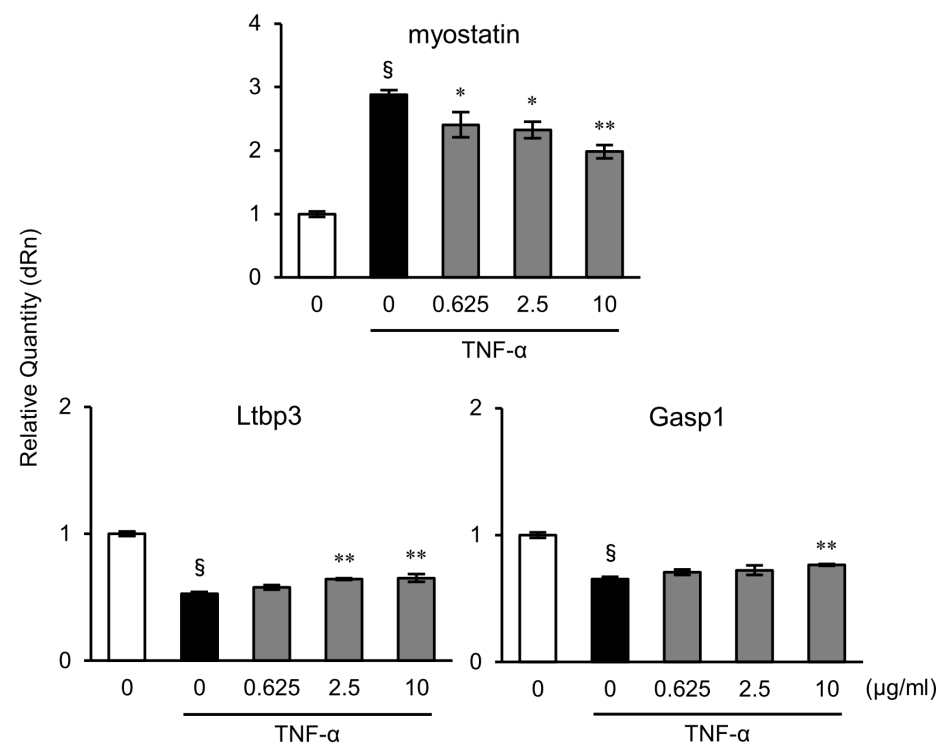

Figure 5. Relative mRNA expressions in myotubes in the absence or presence of AOSs mixture, exposed or not exposed to TNF- $\alpha$ for $24 \mathrm{~h}$. Data are presented as the mean \pm SEM $(n=3) .{ }^{5} P<0.05$ (Student's t-test, two-sided) compared to the TNF- $\alpha$-free control; ${ }^{\star} P<0.05,{ }^{*} P<0.01$ (Dunnett's multiple comparison test, two-sided) compared to the TNF- $\alpha$-added control.

TNF- $\alpha$-added control was significantly lower than that of the TNF- $\alpha$-free control. However, the mRNA expressions of both Ltbp3 and Gasp1 in myotubes exposed to TNF- $\alpha$ and treated with AOSs mixture (at 2.5 and $10 \mu \mathrm{g} / \mathrm{ml}$ for Ltbp3, and $10 \mu \mathrm{g} / \mathrm{ml}$ for Gasp1) were significantly greater than that of the TNF- $\alpha$-added control.

\subsection{Effect of Each AOS on Myostatin mRNA Expression in TNF- $\alpha$-Exposed Myotubes}

Figure 6 shows the effects of each AOS (i.e., Abi, Ate, Ahe and Aoc) on the myostatin mRNA expression level in myotubes exposed to TNF- $\alpha$. Abi and Ate (both at $10 \mu \mathrm{M}$ ) significantly reduced the level of myostatin mRNA expression, and Ahe had a slightly lesser effect, compared to the TNF- $\alpha$-added control. Aoc had no effect.

\section{Discussions}

This study reports that AOSs derived from agar had inhibitory effects toward myotube shrinkage, and these effects were associated with a down-regulation of myostatin expression.

We first examined whether AOSs had any cytotoxic or proliferative effects on the cells, even though AOSs (at $1 \mathrm{mg} / \mathrm{ml}$ ) were reported to exhibit no cytotoxic effects on mammalian cells [19]. In the present study, neither the number nor the titer of cells treated with AOSs mixture (at $0.625,2.5$ and $10 \mu \mathrm{g} / \mathrm{ml}$ ) was significantly different from the AOSs mixture-free control (Figure 2(A)). In addition, we investigated whether AOSs had any effect on the differentiation of the 


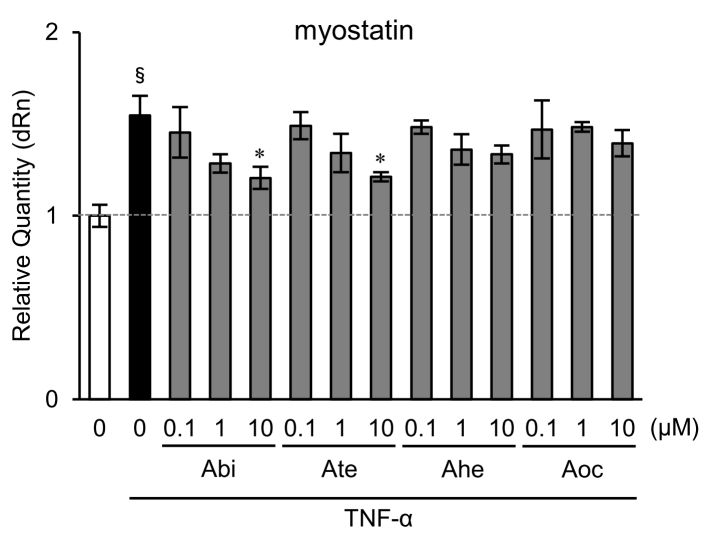

Figure 6. Relative myostatin mRNA expressions in myotubes in the absence or presence of Abi, Ate, Ahe or Aoc (at $0.1,1$ or $10 \mu \mathrm{M}$ ) exposed or not exposed to TNF- $\alpha$. Data are presented as the mean \pm SEM $(n=3) .{ }^{\S} P<0.05$ (Student's t-test, two-sided) compared to the TNF- $\alpha$-free control (the white column); ${ }^{\star} P<0.05$ (Dunnett's multiple comparison test, two-sided) compared to the TNF- $\alpha$-added control (the black column).

cells. The expression levels of myogenic marker mRNAs, i.e., myogenin and Mlc3f mRNAs, were not significantly different compared to that of the AOSs mixture-free control (Figure 2(B)). Zammit et al. reported that myogenin and Mlc3f mRNAs are markers of myotube composition [18]. Our results indicate that AOSs may have little effect on the cell viability and differentiation.

We next examined whether AOSs prevented a TNF- $\alpha$-induced decrease in myotube size and increase in myotube protein degradation. Exposure of myotubes to TNF- $\alpha$ reduced the diameters by $20 \%-25 \%$ (Figure 3) and stimulated $\mathrm{MyHC}$ protein degradation by approximately $20 \%$ (Figure 4). Importantly, both the TNF- $\alpha$-induced increase in myotube shrinkage and MyHC protein degradation were prevented by AOSs mixture. These results suggest that AOSs influence the increase in MyHC protein amount in the myotubes exposed to TNF- $\alpha$, thereby preventing myotube shrinkage. Moreover, the level of MyHC protein in the myotubes exposed to TNF- $\alpha$ and treated with AOSs mixture (at $10 \mu \mathrm{g} / \mathrm{ml}$ ) was significantly increased compared to that of the TNF- $\alpha$-free control (Figure 4, $P$ $=0.00074)$. This result indicates that AOSs might affect the accumulation of $\mathrm{MyHC}$.

It is known that cytokines are involved in the onset of myotube protein degradation [20], but little is known about the specific targets of these mediators for activating proteolysis. Enhanced expressions of myostatin in TNF- $\alpha$-exposed myotubes have been reported [21]. In the present study, the level of myostatin mRNA expression in myotubes exposed to TNF- $\alpha$ was significantly greater than that of the TNF- $\alpha$-free control. However, the level of myostatin mRNA expression in TNF- $\alpha$-exposed myotubes treated with AOSs mixture was significantly greater than that of the AOSs mixture-free control (Figure 5). These results indicate that the preventative effect of AOSs on MyHC protein degradation may be due to the suppression of myostatin mRNA expression.

Myostatin is known to be regulated by at least four different inhibitors. The 
mechanism of myostatin inhibition remains elusive, and crosstalk between the different intrinsic inhibitors similarly remains unclear [22]. One inhibitor, Ltbp3, binds directly to myostatin to form an inactive myostatin/LTBP3 complex [23]. Another inhibitor, Gasp1, can also bind to myostatin and may regulate the activation of myostatin through proteolytic cleavage [24]. In the present study, the levels of Ltbp 3 and Gasp1 mRNA expression in TNF- $\alpha$-exposed myotubes were significantly lower than that of the TNF- $\alpha$-free control (Figure 5), suggesting that the level of myostatin function might be upregulated in TNF- $\alpha$-exposed myotubes. However, the levels of Ltbp3 and Gasp1 mRNA expression in TNF- $\alpha$-exposed myotubes treated with AOSs mixture (at 2.5 and 10 $\mu \mathrm{g} / \mathrm{ml}$ for Ltbp3, and $10 \mu \mathrm{g} / \mathrm{ml}$ for Gasp1) were significantly greater than that of the TNF- $\alpha$-added control, indicating that AOSs might suppress myostatin function by upregulating the expressions of the myostatin inhibitors.

AOSs such as Abi, Ate and Ahe have been reported to inhibit nitrite production in lipopolysaccharide-stimulated RAW264.7 murine macrophages, and 3,6-anhydro-L-galactose, the reducing end of these AOSs, may play a crucial role in this inhibition [8]. It was also reported that an accumulation of nitrite may be related to myostatin expression in myotubes [25]. In the present study, Abi and Ate (at $10 \mu \mathrm{M}$ both) significantly reduced the level of myostatin mRNA expression, and Ahe had a slightly lesser effect, compared to the TNF- $\alpha$-added control (Figure 6). The concentration of $10 \mu \mathrm{M}$ of Abi was $3.24 \mu \mathrm{g} / \mathrm{ml}$, and that of Ate was $6.30 \mu \mathrm{g} / \mathrm{ml}$. The level of myostatin mRNA expression in myotubes exposed to TNF- $\alpha$ and treated with AOSs mixture (at $0.625,2.5$ and $10 \mu \mathrm{g} / \mathrm{ml}$ ) was significantly lower than that of the TNF- $\alpha$-added control (Figure 4). These results suggested that Abi and Ate in the AOSs were effectively suppressed the expression level of myostatin mRNA, and indicate that the preventive effects of AOSs toward the myotube shrinkage induced by TNF- $\alpha$ might be due to the action of 3,6-anhydro-L-galactose suppressing the accumulation of nitrite in the myotubes.

\section{Conclusion}

The present study demonstrated the inhibitory effect of AOSs on TNF- $\alpha$ induced $\mathrm{C} 2 \mathrm{C} 12$ myotube shrinkage via the regulation of myostatin expression. Consequently, AOSs may be important regulatory oligosaccharides in maintaining myotube mass and tone, and therefore be advantageous for maintaining a healthy status.

\section{References}

[1] Attaix, D., Baracos, V.E. and Pichard, C. (2012) Muscle Wasting: a Crosstalk between Protein Synthesis and Breakdown Signalling. Current Opinion in Clinical Nutrition and Metabolic Care, 15, 209-210. https://doi.org/10.1097/MCO.0b013e328352b80c

[2] Bonaldo, P. and Sandri, M. (2013) Cellular and Molecular Mechanisms of Muscle Atrophy. Disease Models and Mechanisms, 6, 25-39. 
https://doi.org/10.1242/dmm.010389

[3] Rodriguez, J., Vernus, B., Chelh, I., Cassar-Malek, I., Gabillard, J.C., Hadj Sassi, A., Seiliez, I., Picard, B. and Bonnieu, A. (2014) Myostatin and the Skeletal Muscle Atrophy and Hypertrophy Signaling Pathways. Cellular and Molecular Life Sciences, 71, 4361-4371. https://doi.org/10.1007/s00018-014-1689-x

[4] Wang, M., Yu, H., Kim, Y.S., Bidwell, C.A. and, Kuang, S. (2012) Myostatin Facilitates Slow and Inhibits Fast Myosin Heavy Chain Expression during Myogenic Differentiation. Biochemical and Biophysical Research Communications, 426, 83-88. https://doi.org/10.1016/j.bbrc.2012.08.040

[5] McPherron, A.C. and Lee, S.J. (1997) Double Muscling in Cattle due to Mutations in the Myostatin Gene. Proceedings of National Academy of Sciences of the United State of America, 94, 12457-12461. https://doi.org/10.1073/pnas.94.23.12457

[6] Lee, S.J. and McPherron, A.C. (1999) Myostatin and the Control of Skeletal Muscle Mass: Commentary. Current Opinion in Genetics and Development, 9, 604-607. https://doi.org/10.1016/S0959-437X(99)00004-0

[7] Schuelke, M., Wagner, K.R., Stolz, L.E., Hübner, C., Riebel, T., Kömen, W., Braun, T., Tobin, J.F. and Lee, S.J. (2004) Myostatin Mutation Associated with Gross Muscle Hypertrophy in a Child. The New England Journal of Medicine, 351, 2682-2688. https://doi.org/10.1056/NEJMoa040933

[8] Enoki, T., Okuda, S., Kudo, Y., Takashima, F., Sagawa, H. and Kato, I. (2010) Oligosaccharides from Agar Inhibit Pro-Inflammatory Mediator Release by Inducing Heme Oxygenase 1. Bioscience, Biotechnology, and Biochemistry, 74, 766-770. https://doi.org/10.1271/bbb.90803

[9] Higashimura, Y., Naito, Y., Takagi, T., Tanimura, Y., Mizushima, K., Harusato, A., Fukui, A., Yoriki, H., Handa, O., Ohnogi, H. and Yoshikawa, T. (2014) Preventive Effect of Agaro-Oligosaccharides on Non-Steroidal Anti-Inflammatory Drug-Induced Small Intestinal Injury in Mice. Journal of Gastroenterology and Hepatology, 29, 310-317. https://doi.org/10.1111/jgh.12373

[10] Ajisaka, K., Agawa, S., Nagumo, S., Kurato, K., Yokoyama, T., Arai, K. and Miyazaki, T. (2009) Evaluation and Comparison of the Antioxidative Potency of Various Carbohydrates Using Different Methods. Journal of Agricultural and Food Chemistry, 57, 3102-3107. https://doi.org/10.1021/jf804020u

[11] Mirza, K.A., Pereira, S.L., Edens, N.K. and Tisdale, M.J. (2014) Attenuation of Muscle Wasting in Murine C2C12 Myotubes by Epigallocatechin-3-Gallate. Journal of Cachexia, Sarcopenia and Muscle, 5, 339-345. https://doi.org/10.1007/s13539-014-0139-9

[12] Wang, D.T., Yin, Y., Yang, Y.J., Lv, P.J., Shi, Y., Lu, L. and Wei, L.B. (2014) Resveratrol Prevents TNF- $\alpha$-Induced Muscle Atrophy via Regulation of Akt/mTOR/FoxO1 Signaling in C2C12 Myotubes. International Immunopharmacology, 19, 206-213. https://doi.org/10.1016/j.intimp.2014.02.002

[13] Shiota, C., Abe, T., Kawai, N., Ohno, A., Teshima-Kondo, S., Mori, H., Terao, J., Tanaka, E. and Nikawa, T. (2015) Flavones Inhibit LPS-Induced Atrogin-1/MAFbx Expression in Mouse C2C12 Skeletal Myotubes. Journal of Nutritional Science and Vitaminology, 61, 188-194. https://doi.org/10.3177/jnsv.61.188

[14] Kazłowski, B., Pan, C.L. and Ko, Y.T. (2008) Separation and Quantification of Neoagaro- and Agaro-Oligosaccharide Products Generated from Agarose Digestion by $\beta$-agarase and $\mathrm{HCl}$ in Liquid Chromatography Systems. Carbohydrate Research, 343, 2443-2450. https://doi.org/10.1016/j.carres.2008.06.019

[15] Karasawa, K., Uzuhashi, Y., Hirota, M. and, Otani, H. (2011) A Matured Fruit Ex- 
tract of Date Palm Tree (Phoenix dactylifera L.) Stimulates the Cellular Immune System in Mice. Journal of Agricultural and Food Chemistry, 59, 11287-11293. https://doi.org/10.1021/jf2029225

[16] Williamson, D.L., Butler, D.C. and Alway, S.E. (2009) AMPK Inhibits Myoblast Differentiation through a PGC-1 $\alpha$-Dependent Mechanism. American Journal of Physiology-Endocrinology and Metabolism, 297, E304-E314. https://doi.org/10.1152/ajpendo.91007.2008

[17] Sedmak, J.J. and Grossberg, S.E. (1977) A Rapid, Sensitive, and Versatile Assay for Protein Using Coomassie Brilliant Blue G250. Analytical Biochemistry, 79, 544-552. https://doi.org/10.1016/0003-2697(77)90428-6

[18] Zammit, P.S., Partridge, T.A. and Yablonka-Reuveni, Z. (2006) The Skeletal Muscle Satellite Cell: The Stem Cell That Came in from the Cold. Journal of Histochemistry and Cytochemistry, 54, 1177-1191. https://doi.org/10.1369/jhc.6R6995.2006

[19] Chen, H.M. and Yan, X.J. (2005) Antioxidant Activities of Agaro-Oligosaccharides with Different Degrees of Polymerization in Cell-Based System. Biochimica et Biophysica Acta-General Subjects, 1722, 103-111. https://doi.org/10.1016/j.bbagen.2004.11.016

[20] Costelli, P. and Baccino, F.M. (2003) Mechanisms of Skeletal Muscle Depletion in Wasting Syndromes: Role of ATP-Ubiquitin-Dependent Proteolysis. Current Opinion in Clinical Nutrition and Metabolic Care, 6, 407-412. https://doi.org/10.1097/01.mco.0000078984.18774.02

[21] Lenk, K., Schur, R., Linke, A., Erbs, S., Matsumoto, Y., Adams, V. and Schuler, G. (2009) Impact of Exercise Training on Myostatin Expression in the Myocardium and Skeletal Muscle in a Chronic Heart Failure Model. European Journal of Heart Failure, 11, 342-348. https://doi.org/10.1093/eurjhf/hfp020

[22] Elkina, Y., von Haehling, S., Anker, S.D. and Springer, J. (2011) The Role of Myostatin in Muscle Wasting: An Overview. Journal of Cachexia, Sarcopenia and Muscle, 2, 143-151. https://doi.org/10.1007/s13539-011-0035-5

[23] Anderson, S.B., Goldberg, A.L. and Whitman, M. (2008) Identification of a Novel Pool of Extracellular Pro-Myostatin in Skeletal Muscle. Journal of Biological Chemistry, 283, 7027-7035. https://doi.org/10.1074/jbc.M706678200

[24] Hill, J.J., Qiu, Y., Hewick, R.M. and Wolfman, N.M.(2003) Regulation of Myostatin in Vivo by Growth and Differentiation Factor-Associated Serum Protein-1: A Novel Protein with Protease Inhibitor and Follistatin Domains. Molecular Endocrinology, 17, 1144-1154. https://doi.org/10.1210/me.2002-0366

[25] Ketkar, S., Rathore, A., Kandhare, A., Lohidasan, S., Bodhankar, S., Paradkar, A. and Mahadik, K. (2015) Alleviating Exercise-Induced Muscular Stress Using Neat and Processed Bee Pollen: Oxidative Markers, Mitochondrial Enzymes, and Myostatin Expression in Rats. Integrative Medicine Research, 4, 147-160.

https://doi.org/10.1016/j.imr.2015.02.003 